\title{
Vasoconstriction Caused by Cocaine is Enhanced by Sodium Salicylate: Is Inducible Nitric Oxide Synthase mRNA Related?
}

\author{
Mary Irene Mendoza-Baumgart', Marco Pravetoni' and Sheldon B Sparber, ${ }^{*, 1,2}$ \\ 'Department of Pharmacology, University of Minnesota, Minneapolis, MN, USA; ${ }^{2}$ Department of Neuroscience, University of Minnesota, \\ Minneapolis, MN, USA
}

\begin{abstract}
We have previously found that sodium salicylate (NaSal), injected into chicken eggs at nontoxic doses used for quantifying hydroxyl free radicals in hearts and brains of embryos, caused or exacerbated hemorrhages and dramatically reduced hatchability when combined with cocaine (Coc). It has also been reported that inducible nitric oxide synthase (iNOS) gene expression is altered in brain in response to vascular damage and inflammation. In this study we measured diameters of membrane-bound blood vessels (BV) before and after pretreatment with saline $(\mathrm{NaCl})$ or $\mathrm{NaSal}(100 \mathrm{mg} / \mathrm{kg}$ egg), followed by infusion of either $\mathrm{NaCl}$ or Coc $\mathrm{HCl}$ (total of $67.5 \mathrm{mg} / \mathrm{kg}$ egg) during $15 \mathrm{~min}$. Brains and hearts of the embryos were then analyzed for iNOS messenger RNA (mRNA) concentrations. Coc caused vasoconstriction that was significant 5 min postinfusion ( $5 \mathrm{~min} \mathrm{Pl}$ ) of the entire dose (ie after $67.5 \mathrm{mg} / \mathrm{kg}$ egg). Significant vasoconstriction was evident within $5 \mathrm{~min}$ in the group injected with NaSal followed by infusion with Coc (ie after $22.5 \mathrm{mg}$ Coc/ $\mathrm{kg}$ egg). Expression of iNOS mRNA was significantly increased only in the brains of the group exposed to NaSal plus Coc, and the increase was inversely related to BV diameter. These data are discussed in relation to effects of salicylate upon prostanoid synthesis and/or nitric oxide synthesis via iNOS inhibition and their possible relationship to Coc-associated cerebral vascular and/or cardiovascular events in abusing humans. Neuropsychopharmacology (2004) 29, 1294-1300, advance online publication, 3 March 2004; doi:I0.1038/sj.npp. I 30042I
\end{abstract}

Keywords: cocaine; salicylate; blood vessel; chick embryo; inducible nitric oxide synthase; brain

\section{INTRODUCTION}

Cocaine (Coc) use has been linked with cerebrovascular accidents (ie hemorrhage and/or ischemia) in adults (Levine et al, 1991) and in offspring of Coc-using mothers (Frank et al, 1999; Kapur et al, 1991). In addition, rat (Church et al, 1988) and lamb (Akoka et al, 1999) fetuses showed hemorrhages in their brains after Coc exposure during gestation. Coc's effects, however, are not limited to cerebrovascular impairments.

Human and animal studies have shown that Coc use during pregnancy can have detrimental effects to both the mother and the developing organism (Young et al, 1992; Plessinger and Woods, 1993). Headache (Towers et al, 1993), increased blood pressure (Covert et al, 1994), abruptio placentae, preterm labor, and spontaneous abortion (Little et al, 1989; Ryan et al, 1989) are some of the many maternal consequences associated with $\mathrm{Coc}$ use. Teratogenic effects (eg cardiac and skeletal defects) and

*Correspondence: SB Sparber, Department of Pharmacology, University of Minnesota, 6-120 Jackson Hall, 321 Church St SE, Minneapolis, MN 55455-0217, USA, Tel: + I 612625 5657, Fax: + | 612625 8408, E-mail: sparb00I@umn.edu

Received 21 October 2003; revised 05 January 2004; accepted 13 January 2004

Online publication: 15 January 2004 at http://www.acnp.org/citations/ Npp0 I I 50403483/default.pdf neurobehavioral changes (eg seizures, learning, and/or attention deficits) are associated with exposure to $\mathrm{Coc}$ in utero (Young et al, 1992; Plessinger and Woods, 1993; Vorhees et al, 1995).

Coc-using pregnant women suffering from headache may self-medicate with the over-the-counter drug aspirin. If brought to a hospital with symptoms of headache, abdominal pain, blurred vision, and increased blood pressure, these women may be misdiagnosed as suffering from pre-eclampsia (Towers et al, 1993) for which aspirin is often used as part of the treatment. Despite conflicting reports as to the benefits of aspirin in treating preeclampsia (Crandon and Isherwood, 1979; Dekker and Sibai, 2001; Mattar and Sibai, 1999), it is still widely used by clinicians (Bower, 1998).

Aspirin, which has a half-life of approximately $15 \mathrm{~min}$ in humans, is hydrolyzed to salicylate (Sal). Depending on the dose administered, Sal has a half-life of between 2 and $15 \mathrm{~h}$ or more (Furst et al, 1979; Roberts et al, 1983). The present study used sodium salicylate ( $\mathrm{NaSal}$ ) because of its longer half-life and to eliminate the anticoagulant effect from the acetate moiety of aspirin. Aspirin and its metabolite salicylate have also been reported to have teratogenic potential in animals (Kotwani et al, 1994; Mcgarrity et al, 1981; Kimmel et al, 1971). An epidemiological study has suggested that maternal aspirin ingestion during the first half of pregnancy was associated with attention deficits and 
low IQ scores in 4-year-old children (Streissguth et al, 1987). In addition, it has been reported that offspring of pregnant rats administered aspirin may have impairment in learning abilities (Butcher et al, 1972).

We have previously shown that Coc caused vasoconstriction of extra-embryonic blood vessels (BV) and caused herniated umbilici in chick hatchlings (Zhang et al, 1998). Little is known, however, about the effects of combined use of, or exposure to $\mathrm{Coc}$ and Sal, other than what appears to be substantial interactive toxicity, manifest as hemorrhages and associated death of chicken embryos exposed to the combination (Venturini and Sparber, 2001; Castelli et al, 2001). One possible mechanism for the interactive toxicity of the combination of $\mathrm{Coc}$ and NaSal is greatly augmented effects of Coc (eg greater vasoconstriction) leading to greater ischemia and possibly unabated increases in intraluminal pressure, causing hemorrhages and/or inflammation secondary to vasospasm (Zuccarello et al, 1998; Conway and Tamargo, 2002).

It has been reported that there is elevated brain nitric oxide synthase (iNOS) expression following subarachnoid hemorrhage associated with cerebral vasospasm (Sayama et $a l, 1999)$ as well as enhanced iNOS gene expression in brain in response to ischemia and inflammation (del Zoppo et al, 2000; Wong et al, 1996; Moro et al, 1998). Furthermore, it has been demonstrated that uteroplacental ischemia produced an increased iNOS messenger RNA (mRNA) in fetal rat cerebral cortex (Gonzalez-Barrios et al, 2002). The vitelline vessels associated with the chorioallantoic membrane, which we have used to study vascular effects, is considered to be the avian homolog of the mammalian placenta (Metcalfe and Stock, 1993).

To further characterize the potential effects of Coc and $\mathrm{NaSal}$ on the developing embryo, this study was undertaken to determine the effect of this combination on the extraembryonic BV diameter as a marker for altered vascular function and to determine if there is an association between vasoconstriction and the concentration of iNOS mRNA in hearts or brains of exposed embryos.

\section{METHODS}

\section{Subjects}

Fertilized chicken (Gallus domesticus) eggs (White Leghorn $\times$ White Leghorn) were obtained from the University of Minnesota Poultry Nutrition Research facility (St Paul, $\mathrm{MN})$. The eggs were refrigerated at $14-16^{\circ} \mathrm{C}$ for $24-48 \mathrm{~h}$ to synchronize embryogenesis, and were then set in a rotating, forced-air incubator (Humidaire Hatchette, New Madison, $\mathrm{OH})$ at $37.5^{\circ} \mathrm{C}$ and $56-58 \%$ relative humidity. The day the eggs were set was regarded as day zero of embryogenesis (E0).

Eggs were candled on E14 for embryo viability and to locate and mark the aircell and an injection/infusion site about $2 \mathrm{~cm}$ below the aircell, avoiding membrane-bound $\mathrm{BV}$. The injection site was disinfected with a drop of $2 \%$ iodine tincture and washed immediately with cotton gauze dipped in $70 \%$ ethanol. A $1.2-\mathrm{mm}$ dental burr attached to a small drill was used to make a hole through the shell, taking care not to puncture the underlying membrane. The holes were covered with plastic tape (3M, St Paul, MN) and replaced in the incubator.

\section{Drugs and Treatment}

$\mathrm{Coc} \mathrm{HCl}$ was kindly provided by the National Institute on Drug Abuse. NaSal was purchased from Aldrich Chemicals (Milwaukee, WI). Coc and NaSal were dissolved in filtered (Acrodisc $0.2 \mu \mathrm{m}$ filter, Pall Corp, Ann Arbor, MI) distilled water just prior to their use. The dose of Coc was based on previous experiments in our laboratory, within the range that produces moderate to severe effects, including reduced hatchability of chick embryos. The NaSal dose used was devoid of toxicity (ie reduced hatchability) when injected by itself (Castelli et al, 2001). Avian isotonic $\mathrm{NaCl}(0.85 \% \mathrm{w} / \mathrm{v})$ was used for control injections and infusions. In all, 16 eggs with viable embryos were randomly assigned to one of four groups ( $n=4 /$ group). On E15, the eggs were injected with $\mathrm{NaSal}(100 \mathrm{mg} / \mathrm{kg}$ egg) or $20 \mu \mathrm{l} \mathrm{NaCl} 1 \mathrm{~h}$ prior to the start of a 15 -min infusion (min Inf) of either Coc $\mathrm{HCl}(0.23 \mathrm{mg} / \mathrm{egg} /$ $\min$ ) or $\mathrm{NaCl}$. Coc or $\mathrm{NaCl}$ was infused at a volume of $10 \mu \mathrm{l} /$ min. Thus, the four groups were designated $\mathrm{NaCl}+\mathrm{NaCl}$, $\mathrm{NaSal}+\mathrm{NaCl}, \mathrm{NaCl}+\mathrm{Coc}$, and $\mathrm{NaSal}+\mathrm{Coc}$.

\section{Experiment 1: Blood Vessel Visualization, Recording, and Quantifying Vascular Diameter}

The procedure and equipment used are described in detail elsewhere (Zhang et al, 1998). Briefly, a circular $3-4 \mathrm{~cm}$ diameter hole was made over the marked air cell of each egg. Mineral oil $(0.5 \mathrm{ml})$ was dropped onto the exposed membrane to make it transparent and reveal the membrane-bound vasculature. A $1 \mathrm{~cm}$ long, $250-\mu \mathrm{m}$-diameter, 3.0 silk suture, previously soaked in mineral oil, was placed near the desired BV as a reference. The egg was placed upright on a sponge cradle directly under an endoscope (Olympus, model A5257) in an incubator maintained at $37^{\circ} \mathrm{C}$. The injection hole was facing toward the incubator door to facilitate subsequent infusion. The endoscope, which was connected to a color camera (Toshiba)-digital AV mixer (Panasonic)-VCR (Panasonic) system, was lowered until an image of BV and the suture were in focus on a video monitor. A PE-20 polyethylene catheter, with a bulbous expansion as a stop (de Balbian Verster et al, 1971), was inserted into the injection hole extending $3.5 \mathrm{~mm}$ into the egg with the other end connected to a syringe mounted on an infusion pump (Harvard Apparatus, Millis, MA). The egg was allowed to acclimate for $5 \mathrm{~min}$ before a baseline (BL) video recording was made. After $\mathrm{BL}$ recording, an infusion of either $\mathrm{Coc}$ or $\mathrm{NaCl}$ was started. Recordings were made at 5,10 , and $15 \mathrm{~min}$ into the infusion $(5,10$, or $15 \mathrm{~min}$ Inf) and at $5 \mathrm{~min}$ after infusion was stopped $(5 \mathrm{~min}$ postinfusion; $5 \mathrm{~min} \mathrm{PI})$. All recordings were stored on VHS tape for subsequent measurement of the BV and suture diameters. A Macintosh computer equipped with a videospigot frame grabber card (SuperMac Technology, Inc., CA) was used to capture the images from the VHS tapes and convert them to digital format for subsequent image analysis, using NIH Image software (Division of Computer Research and Technology, NIH, Bethesda, MD). The BV and suture widths were measured, in pixels, and were converted to $\mu \mathrm{m}$ by comparison with the suture as a reference. During 
acquisition (ie video recording) and measurement of treatment effects upon BV diameters, the experimenter was blind as to pretreatment and infusions in order to eliminate potential bias.

\section{Experiment 2: Brain and Heart iNOS mRNA Quantification}

RNA isolation. Immediately after $\mathrm{BV}$ visualization and recording, brains and hearts of the embryos were removed and placed in Trizol reagent (Invitrogen, Carlsbad, CA), a phenol and guanidine isothiocyanate solution, in a volume of $1 \mathrm{ml} / 100 \mathrm{mg}$ of tissue. The tissues were homogenized immediately. The RNA extraction procedure performed was derived from the Trizol reagent protocol based on the single-step method of RNA isolation developed by Chomczynski and Sacchi (1987). Chloroform, isopropanol, and diethyl pyrocarbonate (DEPC) were purchased from Sigma (St Louis, MO). The extracted RNA was placed in $300 \mu$ of DEPC-water (1\% v/v DEPC) and incubated at $58^{\circ} \mathrm{C}$ for 10 min to dissolve the RNA completely. The concentration of total RNA in the samples was assessed by spectrophotometry using a wavelength of $260 \mathrm{~nm}$ for RNA, and wavelengths of 280 and $320 \mathrm{~nm}$, respectively, for DNA and protein contamination. Analysis was made using a Soft-Pac module for a DU-64 spectrophotometer (Beckman Instruments, Fullerton, CA)

\section{Reverse Transcription: Production of Complementary DNA from mRNA}

Reverse transcription was performed with $5 \mu \mathrm{g}$ of total RNA from each organ.

RNA and $1.0 \mu \mathrm{l}$ Oligo $\mathrm{d}(\mathrm{T})_{12-18}$ (Invitrogen) were incubated at $70^{\circ} \mathrm{C}$ for $10 \mathrm{~min}$ in $0.2 \mathrm{ml}$ nuclease-free tubes (RPI Corp., Mt Prospect, IL). Following completion of this first heating cycle, $7 \mu \mathrm{l}$ of reaction mixture composed of $1 \times$ first-strand buffer, $10 \mathrm{mM}$ dithiothreitol (DTT), and $0.5 \mathrm{mM}$ deoxynucleotide-3-phosphate mixture (dNTP) (Invitrogen) was added. The tubes were then incubated at $42^{\circ} \mathrm{C}$ for $2 \mathrm{~min}$, after which $200 \mathrm{U}$ of Superscript RNase H- Reverse Transcriptase (Invitrogen) was added. Samples were again incubated at $42^{\circ} \mathrm{C}$ for $50 \mathrm{~min}$, followed by a cycle of $70^{\circ} \mathrm{C}$ for $15 \mathrm{~min}$. The reverse transcription products were stored at $-80^{\circ} \mathrm{C}$ until further use.

\section{Polymerase Chain Reaction for Amplification of cDNA}

A measure of $2 \mu \mathrm{l}$ of the reverse transcription solution containing cDNA was amplified through polymerase chain reaction (PCR) technology. The PCR reaction mixture was composed of $1 \times$ PCR buffer, $1.5 \mathrm{mM} \mathrm{MgCl}_{2}$, $0.2 \mathrm{mM}$ dNTP, $0.5 \mu \mathrm{M} 5^{\prime}$-primer, $0.5 \mu \mathrm{M} 3^{\prime}$-primer, and $2.5 \mathrm{U}$ of Taq DNA polymerase (Invitrogen) dissolved in DEPCwater.

Initial incubation, at $94^{\circ} \mathrm{C}$ for $10 \mathrm{~min}$, was followed by 30 cycles: $94^{\circ} \mathrm{C}$ for $30 \mathrm{~s}, 56^{\circ} \mathrm{C}$ for $1 \mathrm{~min}$, and $72^{\circ} \mathrm{C}$ for $1.5 \mathrm{~min}$. After 30 cycles, samples were incubated at $72^{\circ} \mathrm{C}$ for $10 \mathrm{~min}$. All the incubations were conducted on a GeneMate Genius 120 Thermal Cycler (ISC Bioexpress, Kaysville, UT).

Samples were separately amplified with two different sets of primers: glyceraldehyde-3-phosphate dehydrogenase
(GAPDH) and iNOS. Amplification of GAPDH message was conducted as a qualitative internal control, since we had not previously included iNOS gene products in experiments of this type and to confirm if RT-PCR procedure was working. Although GAPDH is one of the most commonly used housekeeping gene products, GAPDH message was not used as an endogenous quantitative standard in our study, since other studies have shown that the expression of this gene and other housekeeping genes is not, as most experimenters assume, constant. Expression of the so-called housekeeping genes, including GAPDH gene products, can vary as a consequence of drug treatment in hens brain (Damodaran et al, 2002) or during stages of development of bovine preimplantation embryos (Robert et al, 2002). Therefore, only iNOS PCR products from the different groups were quantified via densitometry as described below.

The following primers were used for GAPDH amplification: (5'-primer) $5^{\prime}$-TGTGACTTCAATGGTGACA and $\left(3^{\prime}\right.$ primer) 5'-CAGATCAGTTTCTATCAGC.

The iNOS primers were: (5'-primer) $5^{\prime}$-TTCAAACCTCATGCTGTTAA and ( $3^{\prime}$-primer) $5^{\prime}$-ACTGTAGTACTGCTTGAGAA. All primers were custom-made and purchased from Invitrogen. The primers were based upon the sequence retrieved from NCBI GenBank database from the coding sequence of chicken (G. domesticus): GAPDH (accession M11213) and iNOS (accession U46504).

\section{Polyacrylamide Gel Electrophoresis to Separate PCR Products for Densitometry}

The PCR products from GAPDH and iNOS mRNA were separated on a vertical electrophoresis unit (Owl Separation Systems, Portsmouth, NH) using a polyacrylamide gel. Each gel was composed of $2.6 \mathrm{mM}$ ammonium persulfate, TBE buffer $(0.1 \mathrm{M}$ Tris, $0.09 \mathrm{M}$ boric acid, $1 \mathrm{mM}$ EDTA) (Invitrogen), $3.8 \%(\mathrm{w} / \mathrm{v})$ acrylamide, $0.2 \%(\mathrm{w} / \mathrm{v})$ bisacrylamide (BioRad, Hercules, CA), $0.1 \%$ (v/v) TEMED $\left(N, N, N^{\prime}, N^{\prime}\right.$-tetramethylethylenediamine) (Sigma), and ultrapure deionized water.

The PCR products were pipetted onto each well of the gel in a total loading volume of $18 \mu \mathrm{l}$, composed of $15 \mu \mathrm{l}$ of PCR reaction solution combined with loading buffer $(0.25 \% \mathrm{w} / \mathrm{v}$ bromphenol blue, $30 \% \mathrm{v} / \mathrm{v}$ glycerol (Sigma) in ultrapure deionized water). In each gel, three lanes were loaded with a $50 \mathrm{bp}$ DNA Molecular Weight Ladder (Invitrogen). GAPDH and iNOS PCR products from samples from the control and the treated groups were loaded on each gel.

The gels were run at $50 \mathrm{~mA}$ for about $1 \mathrm{~h}$ or when the bromphenol blue dye of the loading buffer reached the bottom of the vertical gel, and then stained for $10 \mathrm{~min}$ in $0.01 \%(\mathrm{w} / \mathrm{v})$ ethidium bromide (Sigma) solution. PCR products were visualized using Gel Doc 1000 apparatus (Biorad) and the images transferred to a Macintosh computer. Densitometric quantification of the bands obtained from the iNOS PCR products was carried out using Molecular Analyst software (Biorad). Although cDNAs were the products amplified, separated, and quantified, we refer to them as the starting nucleic acid (ie mRNA). 


\section{Statistical Analysis}

BV and suture values obtained during and after infusions were expressed and analyzed as percent of their individual BL values because of the large variability between subjects. The values for iNOS message were obtained from densitometric analysis and expressed as pixels/band.

Repeated-measures ANOVA followed by factorial ANOVAs was used for statistical comparisons where appropriate. Based on a previous study (Zhang et al) showing the vasoconstrictive effect of Coc upon the chick's extraembryonic vasculature, unidirectional Dunnett's test was used as the preplanned contrast to compare BV diameters of each treated group against the control group. Least square linear regression analysis between brain or heart mRNA and BV diameters was also carried out.

\section{RESULTS}

\section{Experiment 1: Blood Vessel Experiment}

Examples of images of the BV from eggs with various treatments are shown in Figure 1. Baseline BV diameters of the four treatment groups, while quite variable, were nevertheless not significantly different from one another. The mean absolute value for BL diameters was $231 \mu \mathrm{m}$, ranging in size from 189 to $273 \mu \mathrm{m}(n=16)$.

Repeated-measures ANOVA showed a significant main effect of treatment $\left(\mathrm{F}_{3,12}=7.37 ; p<0.005\right)$ and a repeatedmeasures effect $\left(\mathrm{F}_{3,12}=4.485 ; p<0.01\right)$. There was also a significant treatment effect by repeated-measures interaction $\left(\mathrm{F}_{9,36}=3.29 ; p=0.005\right)$. Examination of Figure 2 shows that $\mathrm{BV}$ diameters, relative to their respective BL diameters, did not vary by more than a few percent for the $\mathrm{NaCl}+\mathrm{NaCl}$ group and the $\mathrm{NaSal}+\mathrm{NaCl}$ group at all times. The $\mathrm{NaCl}+\mathrm{Coc} \mathrm{BV}$ diameters were not significantly affected for the first three time points (ie 5, 10, and $15 \mathrm{~min}$ Inf). Unidirectional Dunnett's test showed that BV diameters
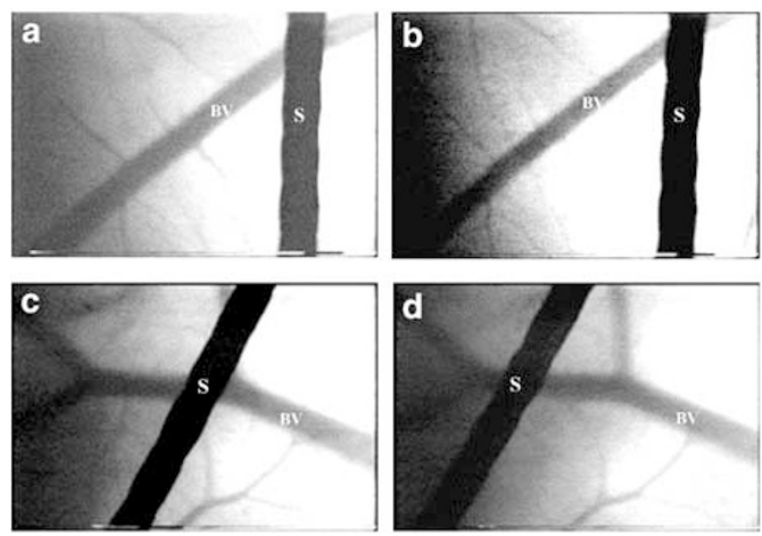

Figure I Sample BV image. Panels a and $\mathrm{c}$ are images from recordings made at baseline while panels $b$ and $d$ are images from recordings made after 5 min into infusion of Coc. Panels $a$ and b show an obvious reduction in BV diameter, relative to baseline diameter, measured where BV is superimposed upon the images, from a subject in the NaSal + Coc group. Panels $\mathrm{c}$ and $\mathrm{d}$ show no apparent effect in a subject from the $\mathrm{NaCl}+\mathrm{Coc}$ group. $\mathrm{S}$ is superimposed upon the images where measurements were taken for diameters of the sutures. from the Coc-only-treated group took $20 \mathrm{~min}$ (ie $15 \mathrm{~min}$ of Coc Inf $+5 \mathrm{~min}$ PI) to cause a significant (18\%) reduction in diameter (ie vasoconstriction) compared to the $\mathrm{NaCl}+\mathrm{NaCl}$-treated group, while pretreatment with $\mathrm{NaSal}$ sensitized the vasculature to the vasoconstrictive effect of Coc, causing a significant $(12 \%)$ reduction in vascular size immediately (ie within $5 \mathrm{~min}$ Inf), showing progressively greater vasoconstriction over the 20 min recording period with a $17 \%$ decrease in $\mathrm{BV}$ diameter at this time.

\section{Experiment 2: Brain iNOS mRNA}

Figure 3 shows an example of a gel containing samples from each treated group, along with the molecular weight ladder. Dunnett's test indicated that only the $\mathrm{NaSal}+\mathrm{Coc}$-treated group showed a significant increase in iNOS mRNA in their brains compared with the $\mathrm{NaCl}+\mathrm{NaCl}$ group's brains (Figure 4). The concentration of iNOS mRNA in the hearts of the treated groups was not different from controls (data

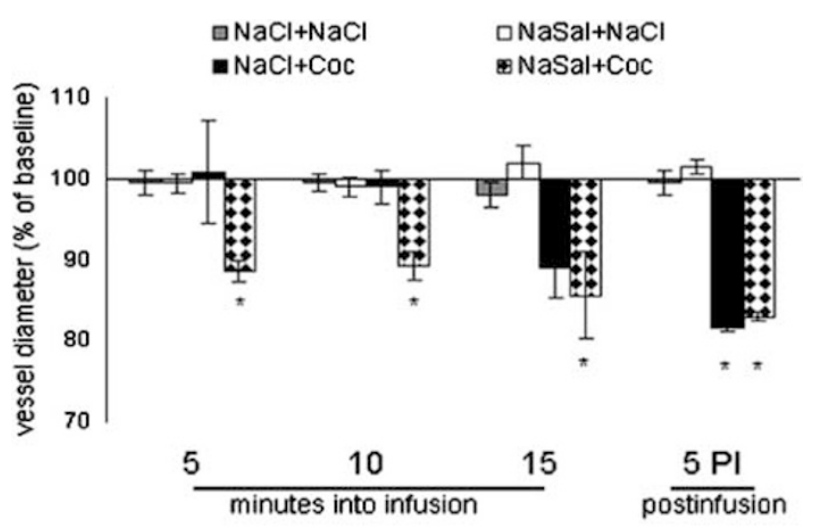

Figure 2 BV diameter. Combined $\mathrm{NaSal}+\mathrm{Coc}$ decreased BV diameter as soon as 5 min into the infusion, while $\mathrm{Coc}$ alone (ie $\mathrm{NaCl}+\mathrm{Coc}$ ) did not have an effect until 5 min Pl. ${ }^{*} p<0.05$ or better vs controls $(\mathrm{NaCl}+\mathrm{NaCl})$ using unidirectional Dunnett's test. Values are expressed as \% of baseline $\mathrm{BV}$ diameter. Vertical lines represent \pm SEM.

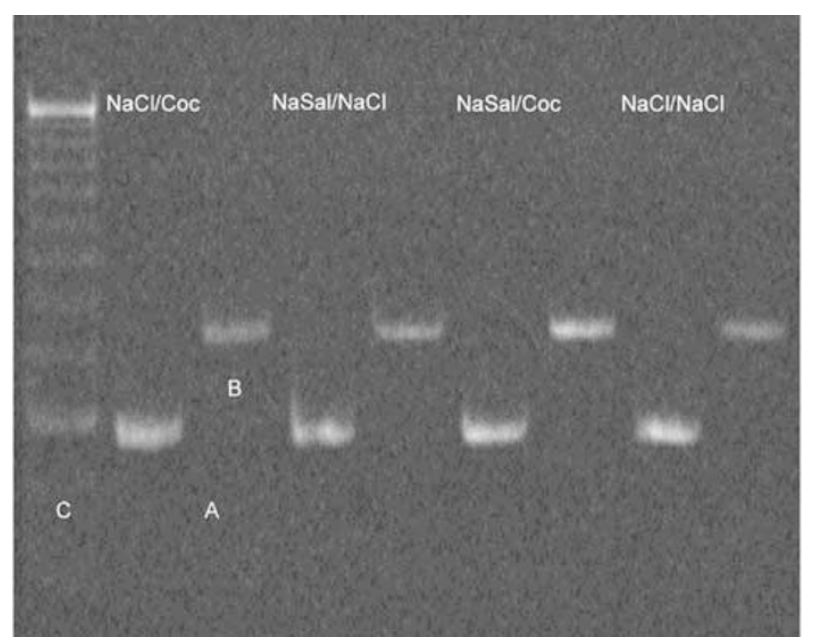

Figure 3 Sample of a gel showing cDNA bands derived from extracted mRNA for the 'housekeeping' GAPDH gene (A) and iNOS gene (B). (C) The 50 bp cDNA ladder. 


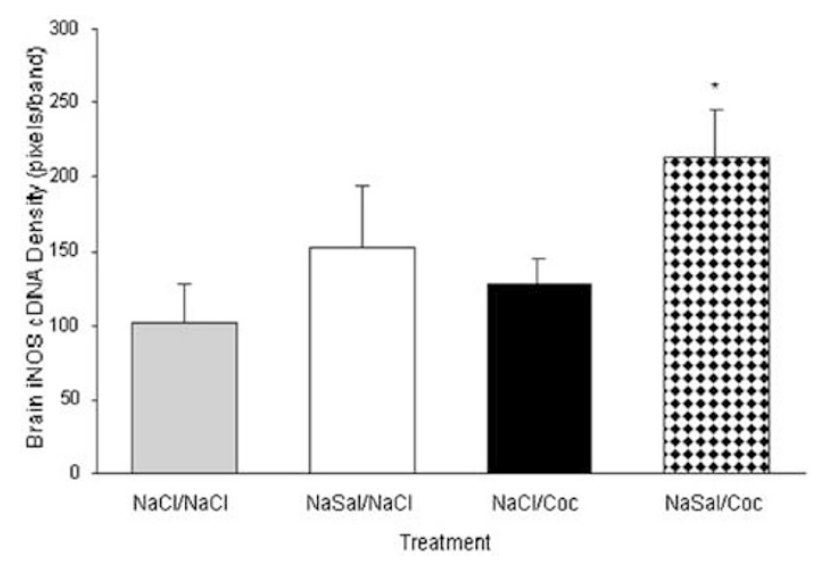

Figure 4 Brain iNOS mRNA expression. Only the NaSal + Coc-treated group demonstrated an increase in iNOS mRNA expression. ${ }^{*} p<0.05$, Dunnett's test. Vertical lines represent SEM.

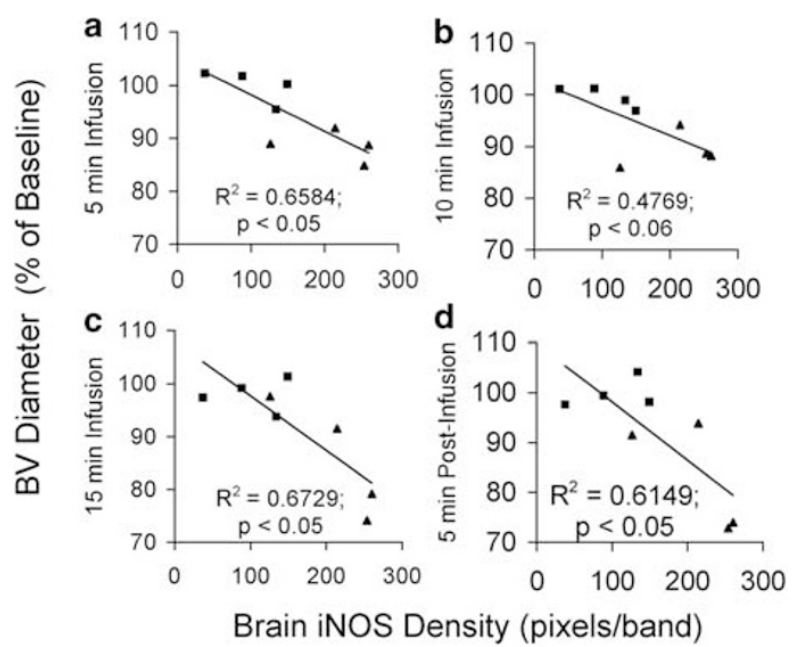

Figure 5 Regression analysis of brain iNOS vs BV size. There are significant inverse relationships between $\mathrm{BV}$ size and brain iNOS mRNA expression at three of the four times during and after infusions. Values used are from the $\mathrm{NaCl}+\mathrm{NaCl}$ and $\mathrm{NaSal}+\mathrm{Coc}$ groups. All other treatment combinations did not show significant relationships. $\mathrm{NaCl}+\mathrm{NaCl}$ data; $\Delta \mathrm{NaSal}+\mathrm{Coc}$ data.

not shown). Regression analyses were carried out on data derived from the $\mathrm{NaCl}+\mathrm{NaCl}$ and $\mathrm{NaSal}+\mathrm{Coc}(n=4+4)$ since only the $\mathrm{NaSal}+\mathrm{Coc}$ group showed a significant increase in expression of iNOS message. The outcome of the regression analysis is displayed in Figure 5, which shows results for all four times (ie 5, 10, $15 \mathrm{~min}$ inf, and $5 \mathrm{~min}$ PI).

\section{DISCUSSION}

NaSal by itself did not have an effect upon BV size. However, NaSal greatly enhanced the vasoconstriction caused by Coc on the extra-embryonic vasculature.

Coc by itself caused vasoconstriction, as expected, but not until $5 \mathrm{~min}$ after the infusion was terminated. When pretreated with NaSal, the BV diameters decreased significantly as soon as $5 \mathrm{~min}$ into the infusion, the earliest time taken for analysis. The mechanisms responsible for the interactive effect of the combination of $\mathrm{NaSal}+\mathrm{Coc}$ upon the vasculature of the homolog of the mammalian placenta are most likely due to several actions. For example, inhibition of synthesis of the potent vasodilator prostacyclin by NaSal (Shimokawa et al, 1988; Vane and Botting, 1998) may have contributed to the inability of the $\mathrm{BV}$ to counteract the effect of $\mathrm{Coc}$, resulting in enhanced vasoconstriction. Another possibility is that, as NaSal blocks the cyclooxygenase pathway, arachidonic acid metabolism may shift toward increased production of leukotrienes, which have been demonstrated to have vasoactive effects in human placenta (Thorp et al, 1988), ovine fetoplacental circulation (Meyer et al, 1990), and in guinea pig cerebral arteries (Uski and Hogestatt, 1992), and consequently exacerbate the vasoconstriction caused by Coc. The enhanced vasoconstriction caused by combined $\mathrm{NaSal}+\mathrm{Coc}$ may decrease blood supply to the embryo, leading to organ (eg brain) hypoperfusion and hypoxia (Covert et al, 1994). Alternatively, the $\mathrm{NaSal}+\mathrm{Coc}$-induced reduction in the diameter of the $\mathrm{BV}$ can dramatically increase resistance, based on Poiseuille equation $(R=8 n L /$ $\left.\pi r^{4}\right)$ and most likely cause an increase in blood pressure (hypertension) similar to that observed in fetal sheep following an increase in uterine vascular resistance caused by Coc (Covert et al, 1994). Hypertension increases transmural BV pressure, which may compromise BV wall integrity and lead to vascular leakage or rupture evidenced by edema and/or hemorrhages (Lou, 1980). In another study, Mangiardi et al (1988) reported that hypertension (eg Coc induced) is associated with development of subarachnoid or intracerebral hemorrhages and is related to increase blood pressure.

The enhanced vasoconstriction observed in this study and/or the hemorrhages reported previously (Venturini and Sparber, 2001; Castelli et al, 2001) by $\mathrm{NaSal}+\mathrm{Coc}$ can activate vasospastic-related inflammatory processes in the brain (Zuccarello et al, 1998; Conway and Tamargo, 2002). For example, angiographic inflammatory changes (ie poor vascularization and vessel wall irregularities) in rabbits are presumed to occur due to a vasospastic mechanism (Martinez et al, 1996). In addition, the enhanced vasoconstriction seen with the combination of $\mathrm{NaSal}+\mathrm{Coc}$ may lead to ischemia and induce inflammatory reactions, such as microglial cell activation (Garcia et al, 1993) and/or intravascular leukocyte adhesion to the cerebral endothelium (Garcia et al, 1994). An increase in leukotriene production, as mentioned earlier, may also induce inflammatory changes (Henderson, 1994). The inflammatory processes may stimulate microglial cells to produce inflammatory cytokines, like interleukin-1-beta (Il-1 $\beta$ ), which can lead to iNOS mRNA expression (Mizushima et al, 2002; del Zoppo et al, 2000).

While it has been reported that Sal blocks induction of iNOS expression, possibly by inhibiting iNOS at the level of transcription, through an NF-K $\beta$-independent mechanism (Farivar and Brecher, 1996), several other studies suggest that NaSal is interfering with iNOS at a post-transcriptional level, rather than at the level of mRNA transcription. For example, NaSal inhibited iNOS protein synthesis and consequently NO production but did not affect iNOS mRNA expression in RAW 264.7 macrophages exposed to 
lipopolysaccharide (LPS) plus interferon-gamma (INF- $\gamma$ ) (Ryu et al, 2000). The same authors found no effect of $\mathrm{NaSal}$ on iNOS mRNA stability (ie at the post-transcriptional level) similar to a report that NaSal does not affect iNOS mRNA half-life, therefore not altering iNOS mRNA stability (Farivar and Brecher, 1996). In another study, NaSal inhibited IL-1 $\beta$-induced NO formation by blocking iNOS protein synthesis by either NF-K $\beta$ activation or iNOS mRNA expression in rat hepatocytes (Sakitani et al, 1997). Thus, it can be argued that Sal is not a transcriptional inhibitor of iNOS and does not alter mRNA stability (such as mRNA half-life), but it interferes with translational and post-translational processing of iNOS (Amin et al, 1995).

If Sal interferes with translational and/or post-translational events, this may result in decreased iNOS enzyme synthesis with a consequent decrease in NO production. Such an action could partially explain why the vasoconstriction is enhanced while the vascular bed is exposed to the Coc insult after injection of NaSal into eggs with embryos. If Sal is interfering with compensatory mechanisms, such as inhibiting the synthesis of vasodilatory prostaglandins, which relax vascular smooth muscle, and, at the same time, is blocking iNOS protein production and/or decreasing its catalytic activity, the synergy of these actions may be great enough to augment the developmental toxicity of Coc, as previously reported by this laboratory (Venturini and Sparber, 2001; Castelli et al, 2001).

In the absence of sufficient compensatory synthesis and release of NO in response to Coc-induced vasoconstriction, the insult may cause a compensatory increase in iNOS mRNA production. In the present study, we show that increased iNOS mRNA is significantly correlated with the degree of vasoconstriction when Coc is combined with Sal and we interpret these findings thusly.

It has recently been reported that compromised relative cerebral blood flow (rCBF) in abstinent Coc abusers could be significantly reversed by treatment with the protonpump inhibitor ameloride; aspirin was essentially devoid of this effect (Kosten et al, 2003). While it had previously been suggested to use these compounds to treat ischemia-related hypoperfusion of brain in Coc abusers, the potential for aspirin-related bleeding was mentioned as a cautionary factor (Kosten, 1998). Since, the combination of aspirin or Sal plus Coc was not studied with regard to $\mathrm{rCBF}$, the possibility of a vasospastic or hemorrhagic event cannot be ruled out.

We can therefore conclude that the combination $\mathrm{Na}$ $\mathrm{Sal}+\mathrm{Coc}$ may be detrimental to a developing embryo if exposed to combinations of both drugs when, for example, Coc-using pregnant women medicate (self or prescribed) with aspirin. It remains to be determined if other nonsteroid anti-inflammatory agents also enhance the developmental toxicity or vasoconstrictive actions of Coc. We have recently carried out experiments with the NOS inhibitor L-nitro-arginine-methyl-ester or the selective iNOS inhibitor aminoguanidine (Misko et al, 1993), and have likewise found enhanced effects of Coc upon hatchability and/or vasoconstriction (unpublished observations), supporting the tentative interpretation of our results, as discussed above.

\section{ACKNOWLEDGEMENTS}

This work was supported in part by US Public Health Service Grants R37 DAO4979 and T32 DAO7097 and a grant-in-aid from the Minnesota Medical Foundation (3200922-02).

\section{REFERENCES}

Akoka S, Descamps P, Genberg C, Franconi F, Arbeille B, Laurini R et al (1999). Cerebral MRI on fetuses submitted to repeated cocaine administration during the gestation: an ovine model. Obstet Gynecol Reprod Biol 85: 185-190.

Amin AR, Vyas P, Attur M, Leszczynska-Piziak J, Patel IR, Weissmann $G$ et al (1995). The mode of action of aspirin-like drugs: effect on inducible nitric oxide synthase. Proc Natl Acad Sci USA 92: 7926-7930.

de Balbian Verster F, Robinson CA, Hergeveld CA, Bush ES (1971). Freehand cerebroventricular injection technique for unanesthesized rats. Life Sci 10: 1395-1402.

Bower H (1998). Studies reject aspirin for prevention of preeclampsia. BMJ 316: 881.

Butcher RE, Vorhees CV, Kimmel CA (1972). Learning impairment from maternal salicylate treatment in rats. Nat New Biol 236: 211-212.

Castelli MC, Venturini L, Sparber SB (2001). Cocaine and salicylate: documentation of hydroxyl radical formation in hearts and brains of 18-day-old chick embryos and unexpected interactive toxicity. Psychopharmacology 156: 23-31.

Chomczynski P, Sacchi N (1987). Single-step method of RNA isolation by acid guanidinium thiocyanate-phenol-chloroform extraction. Anal Biochem 162: 156-159.

Church MW, Dintcheff BA, Gessner PK (1988). Dose-dependent consequences of cocaine on pregnancy outcome in the LongEvans rat. Neurotoxicol Teratol 10: 51-58.

Conway JE, Tamargo RJ (2002). Cocaine use is an independent risk factor for cerebral vasospasm after aneurysmal subarachnoid hemorrhage. Stroke 33: 1747-1748.

Covert RF, Schreiber MD, Tebbet IR, Torgerson LJ (1994). Hemodynamic and cerebral blood flow effects of cocaine, cocaethylene and benzoylecgonine in conscious and anesthesized fetal lambs. J Pharmacol Exp Ther 270: 118-126.

Crandon AJ, Isherwood DM (1979). Effect of aspirin on incidence of pre-eclampsia. Lancet 1: 1365.

Damodaran TV, Abdel-Rahman A, El-Sourady M, Abou-Donia MB (2002). Differential alteration of glyceraldehyde-3-phosphate dehydrogenase (GAPDH) mRNA in the central nervous system of hens treated with diisopropylphosphorofluoridate (DFP). Neurochem Int 40: 371-379.

Dekker G, Sibai B (2001). Primary, secondary and tertiary prevention of pre-eclampsia. Lancet 357: 209-215.

Farivar E, Brecher P (1996). Salicylate is a transcriptional inhibitor of the inducible nitric oxide synthase in cultured cardiac fibroblasts. J Biol Chem 271: 31585-31592.

Frank DA, McCarten KM, Robson CD, Mirochnick M, Cabral H, Park $\mathrm{H}$ et al (1999). Level of in utero cocaine exposure and neonatal ultrasound findings. Pediatrics 104: 1101-1105.

Furst DE, Tozer TN, Melmon KL (1979). Salicylate clearance, the resultant of protein binding and metabolism. Clin Pharmacol Ther 26: 380-389.

Garcia JH, Lui KF, Yoshida Y, Lian J, Chen S, del Zoppo GJ (1994). Influx of leukocytes and platelets in an evolving brain infarct. Am J Pathol 144: 188-199.

Garcia JH, Yoshida Y, Chen H, Li Y, Zhang ZG, Lian J et al (1993). Progression from ischemic injury to infarct following middle cerebral artery occlusion in rat. Am J Pathol 142: 623-635. 
Gonzalez-Barrios JA, Escalante B, Valdes J, Leon-Chavez BA, Martinez-Fong D (2002). Nitric oxide and nitric oxide synthases in the fetal cerebral cortex of rats following transient uteroplacental ischemia. Brain Res 1: 114-122.

Henderson Jr WR (1994). The role of leukotrienes in inflammation. Ann Intern Med 121: 684-697.

Kapur RP, Shaw CM, Shepard TH (1991). Brain hemorrhages in cocaine-exposed human fetuses. Teratology 44: 11-18.

Kimmel CA, Wison JG, Schumacher HJ (1971). Studies on metabolism and identification of the causative agent in aspirin teratogenesis in rats. Teratology 4: 15-24.

Kosten TR (1998). Pharmacotherapy of cerebral ischemia in cocaine dependence. Drug alcohol Depend 49: 133-144.

Kosten TR, Gottschalk PC, Tucker K, Rinder CS, Dey HM, Rinder HM (2003). Aspirin or amiloride for cerebral perfusion defects in cocaine dependence. Drug Alcohol Depend 71: 187-194.

Kotwani A, Mehta VL, Iyengar B (1994). Mechanism of aspirin induced neural tube defect in chick embryo. Indian J Med Res 99: 289-294.

Levine SR, Brust FC, Futrell N, Brass LM, Blake D, Fayad P et al (1991). A comparative study of the cerebrovascular complications of cocaine: alkaloidal versus hydrochloride - a review. Neurology 41: 1173-1177.

Little BB, Snell LM, Klein VR, Gilstrap LC (1989). Cocaine abuse during pregnancy: maternal and fetal implications. Obstet Gynecol 73: 157-160.

Lou HC (1980). Perinatal hypoxic-ischemic brain damage and intraventricular hemorrhage. A Pathogenetic model. Arch Neurol 37: 585-587.

Mangiardi JR, Daras M, Geller ME, Weitzner I, Tuchman AJ (1988). Cocaine-related intracranial hemorrhage. Report of nine cases and review. Acta Neurol Scand 77: 177-180.

Martinez N, Diez-Tejedor E, Frank A (1996). Vasospasm/thrombus in cerebral ischemia related to cocaine abuse. Stroke 27: 147-148.

Mattar F, Sibai B (1999). Prevention of pre-eclampsia. Semin Perinatol 23: 58-64.

McGarrity C, Samani N, Beck F, Gulamhusein A (1981). The effect of sodium salicylate on the rat embryo in culture: an in vitro model for the morphological assesment of teratogenecity. J Anat 133: $257-269$.

Metcalfe J, Stock MK (1993). Current topic: oxygen exchange in the chorioallantoic membrane, avian homologue of the mammalian placenta. Placenta 14: 605-613.

Meyer BA, Walsh SW, Parisi VM (1990). Hemodynamic effects of leukotriene $\mathrm{C} 4$ in ovine fetus. Am J Physiol 259: E851-E855.

Misko TP, Moore WM, Kasten TP, Nickols GA, Corbett JA, Tilton RG et al (1993). Selective inhibition of the inducible nitric oxide synthase by aminoguanidine. Eur J Pharmacol 233: 119-125.

Mizushima H, Zhou CJ, Dohi K, Horai R, Asano M, Iwakura Y et al (2002). Reduced postischemic apoptosis in the hippocampus of mice deficient in interleukin-1. J Comp Neurol 448: 203-216.

Moro MA, De Alba J, Leza JC, Lorenzo P, Fernandez AP, Bentura ML et al (1998). Neuronal expression of inducible nitric oxide synthase after oxygen and glucose deprivation in rat forebrain slices. Eur J Neurosci 10: 445.

Plessinger MA, Woods JR (1993). Maternal, placental and fetal pathophysiology of cocaine exposure during pregnancy. Clin Obstet Gynecol 36: 267-277.

Robert C, McGraw S, Massicotte L, Pravetoni M, Gandolfi F, Sirard MA (2002). Quantification of housekeeping transcript levels during the development of bovine preimplantation embryos. Biol Reprod 67: 1465-1472.

Roberts MS, Rumble RH, Wanwimolruk S, Thomas D, Brooks PM (1983). Pharmacokinetics of aspirin and salicylate in elderly subjects and in patients with alcoholic liver disease. Eur J Clin Pharmacol 25: 253-261.

Ryan L, Ehrlich S, Finnegan L (1989). Cocaine abuse in pregnancy: effects on the fetus and newborn. Neurotoxicol Teratol 9: 295-299.

Ryu YS, Lee JH, Seok JH, Hong JH, Lee YS, Lim JH et al (2000). Acetaminophen inhibits iNOS gene expression in RAW 264.7 macrophages: differential regulation of NF-kB by acetaminophen and salicylates. Biochem Biophys Res Commun 272: 758-764.

Sakitani K, Kitade H, Inoue K, Kamiyama $\mathrm{Y}$, Nishizawa $\mathrm{M}$, Okumura $\mathrm{T}$ et al (1997). The anti-inflammatory drug sodium salicylate inhibits nitric oxide formation induced by interleukin$1 \beta$ at a translational step, but not at a transcriptional step, in hepatocytes. Hepatology 25: 416-420.

Sayama T, Suzuki S, Fukui M (1999). Role of inducible nitric oxide synthase in the cerebral vasospam after subarachnoid hemorrhage in rats. Neurol Res 21: 293-298.

Shimokawa H, Flavahan NA, Lorenz RR, Vanhoutte PM (1988). Prostacyclin releases endothelium-derived relaxing factor and potentiates its action in coronary arteries of the pig. J Pharmacol 95: 1197-1203.

Streissguth A, Treder RP, Barr HM, Shepard TH, Bleyer WA, Sampson PD et al (1987). Aspirin and acetaminophen use by pregnant women and subsequent child IQ and attention decrements. Teratology 35: 211-219.

Thorp JA, Walsh SW, Brath PC (1988). Comparison of the vasoactive effects of leukotrienes with thromboxane mimic in the perfused human placenta. Am J Obstet Gynecol 159: 1376-1380.

Towers CV, Pircon RA, Nageotte MP, Porto M, Garite TJ (1993). Cocaine intoxication presenting as pre-eclampsia and eclampsia. Obstet Gynecol 81: 545-547.

Uski TK, Hogestatt ED (1992). Effects of various cyclooxygenases and lipooxygenases metabolites on guinea pig cerebral arteries. Gen Pharmacol 23: 109-113.

Vane JR, Botting RM (1998). Anti-inflammatory drugs and their mechanism of action. Inflamm Res 47: S78-S87.

Venturini L, Sparber SB (2001). Salicylate and cocaine: interactive toxicity during chicken mid-embryogenesis. Free Radic Biol Med 30: 198-207.

Vorhees CV, Reed TM, Acuff-Smith KD, Schilling MA, Capon GD, Fisher $\mathrm{E}$ et al (1995). Long term learning deficits and changes in unlearned behaviors following in utero exposure to multiple daily doses of cocaine during different exposure periods and maternal plasma concentrations. Neurotox Teratol 17: 253-264.

Wong M, Rettori V, Al-Shekhlee A, Bongiorno PB, Canteros G, MacCann SM et al (1996). Inducible nitric oxide synthase gene expression in the brain during systemic inflammation. Nat Med 2: $581-584$

Young SL, Vosper HJ, Phillips SA (1992). Cocaine: its effects on maternal and child health. Pharmacotherapy 12: 2-17.

Zhang X, Schrott LM, Sparber SB (1998). Evidence for a serotoninmediated effect of cocaine causing vasoconstriction and herniated umbilici in chicken embryos. Pharmacol Biochem Behav 59: 585-593.

del Zoppo G, Ginis I, Hallenbeck JM, Iadecola C, Wang X, Feuerstein GZ (2000). Inflammation and stroke: putative role for cytokines, adhesion molecules and iNOS in brain response to ischemia. Brain Pathol 10: 95.

Zuccarello M, Boccaletti R, Romano A, Rapoport RM (1998). Endothelin B receptor antagonists attenuate subaracnoid hemorrhage-induced cerebral vasospasm. Stroke 29: 1924-1929. 